УДК 342.41:342.565.2

DOI https://doi.org/10.32837/apdp.v0i89.3199

Н. В. Шелевер

\title{
СПРАВЕДЛИВІСТЬ ЯК ОСНОВОПОЛОЖНИЙ ПРИНЦИП ПРАВА
}

Із давніх-давен і до сьогодні питання справедливості цікавить суспільство. Важливою ідеєю людства є справедливе суспільство. Адже несправедливість породжує правовий нігілізм і $є$ небезпечним явищем. Саме з позиції справедливості ми оцінюємо закони, владу, державу. Право та справедливість тісно пов'язані між собою, вони взаємодоповнюють один одного. Проте часто на практиці бувають випадки, коли право не є справедливим за своєю суттю.

Питання справедливості досліджується філософами, політиками, юристами. Це вічна тема філософії та теоретичної юриспруденції. Проте важливо дослідити місце та значення справедливості у системі принципів права.

Принципи права - це ідеї, категорії, які створюються протягом всієї історії розвитку суспільства. За допомогою принципів зберігається баланс між об'єктивною необхідністю суспільного розвитку і суб'єктивною думкою законодавця.

Як зазначає I. Бабич: «Справедливість, як юридична категорія, набуває якості принципу тією мірою, в якій вона втілюється у нормі права. Порівнюючи «справедливість» у правовому та філософському значенні, можна сказати, що втілення справедливості у нормі права означає звуження його застосування. Якщо розглядати принцип справедливості як принцип законодавства, то тут принцип справедливості, здається, збігається з принципом законності» [1, с. 192].

Справедливість - це соціально-юридичний принцип. Позитивне право затверджує справедливість. Тому, на нашу думку, закон має бути правовий, справедливий, оскільки справедливість є критерієм його легітимності.

У самому змісті права уже закладена справедливість. Несправедливість закону призводить до його невиконання. Закон має застосовуватися однаково до всіх. Не може бути ніяких привілеїв чи обмежень. Кожна людина є рівна перед законом та судом. Тому справедливість часто ототожнюють з рівністю.

У відповідності до Загальної декларації прав людини «всі люди народжуються вільними і рівними у своїй гідності та правах» [2]. Цей документ не є обов'язковим для виконання. Проте у відповідності до міжнародних звичаїв положення Декларації є обов'язковими. Ї̈̈ норми присутні у конституціях різних держав і використовуються їх судами. Тому і на даний час відношення вчених до принципу справедливості не змінилося.

Як справедливо зазначає I. Бабич: «Справедливість, впливаючи на право, сама потребує опори на правові норми. Саме право є основним засобом реалізації соціальної справедливості. Справедливість і право є особливо близькими, якщо розглядати їх як засіб досягнення компромісу між протирічними інтересами індивідів, соціальних груп і всього суспільства. Справедливість без права - безсила, право без справедливості - нелюдяне. 
Справедливість проявляє себе як моральна категорія: етичне тлумачення права знаходиться в основі вчень про природне право, в яких право завжди пов'язане із справедливістю, а справедливість завжди пояснюється скрізь ціннісні уявлення про належні відносини людей.

Моральний аспект справедливості є одним із аспектів їі прояву. Розуміння справедливості лише як моральної категорії призводить до помилок. Основою моралі є свобода людини, соціальна справедливість тощо. Мораль є витоком права і принципу справедливості. До того ж принцип справедливості має різні аспекти, серед яких є моральна категорія. Безпосередньо мораль і право необхідно розмежовувати, а моральний аспект права треба сприймати тільки через принцип справедливості» [1, с. 195].

Справедливість - це загальноправовий принцип. Аристотель виділяв два види справедливого. По-перше, «справедливе - це те, що каже робити закон», по-друге, «справедливість по відношенню до іншого є, власне кажучи, рівність» [3, с. 324]. Давньогрецький філософ стверджував, що справедливість - це якість закону.

Справедливість передбачає реалізацію її цінностей у законодавчій, правозастосовній сферах та у правосвідомості. Тобто даний принцип передбачає системність i ï̈ порушення може призвести до негативних і соціально-правових наслідків. На практиці спостерігається ситуація, коли законодавство закріплює справедливість як свій принцип. Проте у законодавця нема обов'язку змінювати чи відміняти ту чи іншу норму права у випадку, якщо вона не відповідає принципу справедливості. Тоді держава має можливість реалізувати несправедливі правові норми, які не захищають права та свободи людини.

Принцип справедливості має бути основоположним у всіх галузях права без виключення. У Конституції України йдеться про те, що бюджетна система України будується на засадах справедливого і неупередженого розподілу суспільного багатства між громадянами і територіальними громадами. Це так звана «розподільча справедливість» .

Як зазначає О. Мартишин: «У всі часи і у всіх народів вважалося, що право повинно бути справедливим. При цьому або воно розглядалося як втілення справедливості, або ставилася ціль привести його у відповідність зі справедливістю. Із цього можна зробити висновок, що справедливість - одна із цінностей права, при чому найбільш довговічна та істотна. Багато цінностей права швидкоминучі... Справедливість належить до числа вічних цінностей чи основних принципів права. Крім справедливості до них можна віднести лише загальне благо і дотримання законів (в широкому значенні слова). Більше того, справедливість - не тільки вічна, але і вища цінність в праві. Всі інші порівнюються з нею і дійсні лише при умові, що вони не суперечать справедливості» [4].

Коли ми оцінюємо діяльність органів влади чи якусь конкретну ситуацію, то керуємося поняттям «справедливо-несправедливо». Поняття «справедливість» є синонімом об'єктивності. У кожному конкретному випадку ми виходимо із власного бачення конкретної ситуації. Позиція юриста повинна базуватися на принципі: діяти справедливо - це діяти у відповідності до вимог права. 
За своїм походженням принцип справедливості є моральним. Він пов'язаний із рівністю, робить людей рівними перед законом і судом. Справедливість - це не лише вимога законодавця. Вона повинна реалізовуватися у правозастосовній практиці.

На думку А. Юнусова, М. Юнусова, М. Водопянової, «1. Справедливість можна розуміти в широкому і вузькому значенні. У широкому - як філософсько-етичну категорію, яка відображає різноманітність суспільно-економічних зв'язків. У вузькому - справедливість розглядається як правова категорія.

2. Справедливість вельми динамічна та має відносний характер. Тому слід розуміти, що справедливість містить у собі елементи несправедливості. Доля несправедливості залежить відправових, економічних, політичних таінших суспільних відносин. Звідси можна визначити таке завдання держави, як підтримання високогорівня справедливості в суспільстві, а також зниження рівня несправедливості» [5, с. 54].

Вважаємо, що для вирішення загальнодержавних питань на підставі критерію «справедливо-несправедливо» треба враховувати інтереси суспільства шляхом проведення загальнодержавних референдумів чи плебісцитів. Для прикладу, можна навести досить болюче для українців питання - це продаж української землі. Постає питання - такий продаж є справедливим чи несправедливим?

Розглянемо іншу ситуацію. Це «рятувальна операція» ПАТ КБ «Приватбанк», який було визнано неплатоспроможним. Такий порятунок коштував українцям 116 млрд. грн. Чи є такі дії держави по відношенню до українського народу справедливими?

Стосовно середньомісячної зарплати в Україні, то слід наголосити, що в нашій державі є чиновники, які отримують заробітну плату мільйони гривнів і є лікарі, які в умовах пандемії COVID-19 ризикують своїм життям та рятують людські життя, отримуючи копійчані надбавки до заробітної плати. Чи є така різниця у заробітній платі справедливою? Вважаємо, що тут має враховуватися такий фактор як ризик життям.

Справедливість - це стержень соціальної держави, яка повинна забезпечувати права людини. Проте проблемним питанням в Україні є те, що до принципу справедливості відносяться досить формально. Часто його розглядають як теоретичний трафарет, який не має практичної користі.

А. Юнусов, М. Юнусов, М. Водопянова зазначають: «Якщо говорити про діалектичний взаємозв'язок справедливості і права, то можна виділити наступні особливості: ідеї справедливості, закріплені в праві, дістають властивість нормативності; у свою чергу, саме право стає справедливим і морально обгрунтованим. Однією із цілей досягнення соціальної справедливості є правове регулювання суспільних відносин за допомогою справедливого законодавства, а закріплення принципу справедливості в праві перетворює його у морально-правовий імператив» [5, с. 54].

Вважаємо, що принцип справедливості, як панівний принцип у праві, має пронизувати усі сфери суспільного життя та активно використовуватися судами у своїй діяльності. Судді повинні не лише формально посилатися на нього. Має бути відповідне обгрунтування. Суддя має дослідити усі обставини справи, підтвердити їх відповідними доказами та довести у рішенні чому на його думку таке рішення є справедливим. 
У своїх рішеннях Конституційний Суд України досить часто посилається саме на принцип справедливості. Так, у рішенні від 02 листопада 2004 № 15-рп/2004 у справі про призначення судом більш м’якого покарання КСУ зазначає: «Справедливість - одна з основних засад права, є вирішальною у визначенні його як регулятора суспільних відносин, одним із загальнолюдських вимірів права. Зазвичай справедливість розглядають як властивість права, виражену, зокрема, в рівному юридичному масштабі поведінки й у пропорційності юридичної відповідальності вчиненому правопорушенню.

У сфері реалізації права справедливість проявляється, зокрема, в рівності всіх перед законом, відповідності злочину і покарання, цілях законодавця і засобах, що обираються для їх досягнення.

Окремим виявом справедливості є питання відповідності покарання вчиненому злочину; категорія справедливості передбачає, що покарання за злочин повинно бути домірним злочину. Справедливе застосування норм права - передусім недискримінаційний підхід, неупередженість. Це означає не тільки те, що передбачений законом склад злочину та рамки покарання відповідатимуть один одному, а й те, що покарання має перебувати у справедливому співвідношенні із тяжкістю та обставинами скоєного і особою винного. Адекватність покарання ступеню тяжкості злочину випливає з принципу правової держави, із суті конституційних прав та свобод людини і громадянина, зокрема права на свободу, які не можуть бути обмежені, крім випадків, передбачених Конституцією України» [6].

Принцип справедливості вимагає однакового застосування закону до осіб, які знаходяться в однакових ситуаціях та диференційованого - до суб'єктів, які знаходяться в різних ситуаціях.

Як стверджує О. Головченко: «Іноді справедливість уявляється чимось ефемерним та декларативним, що використовують передусім для підсилення враження, збудження уяви та додання значущості певній події. Справедливістю часто спекулюють політики, що часом викривляє її справжню цінність та істинну суть. Проте принцип справедливості посідає першорядне місце в законодавстві, а не лише в наукових працях та філософських трактатах. Закон наближає справедливість до дійсності, хоча й не дає їй точного визначення, залишаючи це питання відкритим для тлумачення його теоретиками права» [7].

На погляд О. Головченко, «справедливість за своєю суттю є поняттям релятивним, що віддзеркалює соціальні реалії того чи іншого суспільства, рівень його культурної, правової зрілості. Сьогодні справедливість відіграє роль своєрідного індикатора, який дає конкретне уявлення про відповідність моделі соціальної та правової держави її фактичному стану в суспільстві. Справедливість проявляється на різних суспільних щаблях та в різних просторових і часових вимірах. Так, існує індивідуальна справедливість, яка виражається у ставленні конкретного індивіду до навколишнього світу, існує справедливість між поколіннями, що не обмежена часовими рамками, існує справедливість між народами, націями, державами, яка виходить за межі конкретної території. Можна спробувати розподілити справедливість на види, висловлювати різні про неї міркування, дискутувати, доводити або спростовувати факт їі існування. Але не можна заперечувати важливість значення справедливості для людини і людства, особливо в правовій сфері» [7]. 
Отже, справедливість - це принцип права, який пронизує усю правову систему. Він має бути закріплений у всіх галузях права, а нормативно-правові акти повинні проходити експертизу на відповідність принципу справедливості. Коли принцип справедливості втілюється в праві, то право, тим самим, набуває властивість справедливості.

Як зазначає I. Бабич: «Що стосується принципу справедливості і права, то слід зазначити, що принцип справедливості закладений в самому змісті права. Принципи права виявляються не в конкретній нормі, а у комплексі норм, вони навіть можуть бути не визначеними у нормах права.

Справедливість, що втілена у нормах права, вимагає, щоб закон застосовувався однаково для всіх. Однак не слід забувати, що право не може врахувати всієї багатогранності суспільних відносин. Тому в процесі прийняття рішення посадовцям слід керуватись і буквою закону, і своїм уявленням про справедливість, і тим самим, яке з цих рішень буде найбільш правильним» [1, с. 194].

Тому важливо, щоб працівниками правоохоронних органів та суддями ставали високоморальні особи, які втілюватимуть принцип справедливості у життя. Проблемоює те, що часто спостерігається ситуація, коли чиновники ігнорують моральний зміст принципу справедливості та мають егоїстичний спосіб мислення.

Окрім цього, закони повинні бути справедливі. Наприклад, коли суддя посилається на правову норму, то вона визнається усіма як справедлива. Несправедливі закони не сприймаються як право. Це призводить до правового нігілізму, що $\epsilon$ небезпечним явищем. Несправедливі судові рішення - це зловживання правом із боку суддів. Проблемою в Україні є те, що на практиці дуже часто справедливі закони несправедливо реалізовуються, іцепитання потребує окремого дослідження.

\section{Jimepamypa}

1. Бабич І.Г. Визначення місця принципу справедливості в сучасній системі принципів права. Актуальні проблеми держави і права. С. 191-197.

2. Загальна декларація прав людини від 10.12.1948 року. Офіційний вісник України. 2008. № 93. Ст. 3103.

3. Аристотель. Большая этика. Соч. в 4 т.: пер. с древнегр. Т 4. Москва : Мысль, 1983.830 с.

4. Мартышин О. Справедливость и право. URL : http://journal.zakon.kz. (дата звернення: 03.12.2020).

5. Юнусов А.А., Юнусов М.А., Водопьянова М.В. Методология принципа справедливости в праве. Алтайский юридический вестник. 2018. № 1(21). С. 52-55.

6. Рішення Конституційного Суду України у справі за конституційним поданням Верховного Суду України щодо відповідності Конституції України (конституційності) положень статті 69 Кримінального кодексу України (справа про призначення судом більш м'якого покарання) № 15-рп/2004 від 02.11.2004 року. URL : http://ccu.gov.ua/docssearch?tid $=504 \&$ date_filter $\% 5$ Bvalue $\% 5 \mathrm{D} \% 5 \mathrm{Bdate} \%$ $5 \mathrm{D}=\&$ body_value $=\&$ field_textindex_value=\&field_speaker_value $=($ дата звернення: 07.12.2020).

7. Головченко О. Справедливість як фундаментальний принцип права у практичній площині. URL : http://veche.kiev.ua/journal/3334/ (дата звернення: 10.12.2020). 


\begin{abstract}
Анотація
Шелевер Н. В. Справедливість як основоположний принцип права. - Стаття.

Справедливість - це основоположний принцип, який цікавить теоретиків права та юристів-практиків. Питання справедливості досліджується як філософами, так і юристами. У своїй статті автор досліджує місце та значення справедливості у системі принципів права. Справедливість - загальноправовий принцип, про який писали у своїх працях Аристотель, В. Нерсесянц. Право пов'язане зі справедливістю. Це дві категорії, які взаємно доповнюють одна одну. У змісті права закладена справедливість. Закон повинен бути справедливим, оскільки це є критерієм його легітимності. Справедливість - це і моральна категорія. Мораль є витоком принципу справедливості. Розглядають справедливість і як філософсько-етичну категорію, і як правову категорію. Справедливість динамічна. Вона містить у собі елементи несправедливості, але це залежить від правових, економічних, політичних та інших відносин. Часто справедливість ототожнюють з рівністю. Про це йдеться і в Загальній декларації прав людини. Справедливість має досить важливе значення в юридичній практиці. Питання «справедливо-несправедливо» є болючим для українців. Прикладом є ринок української землі, націоналізація ПАТ КБ «Приватбанк», несправедливі заробітні плати в Україні. Проблемним питанням на практиці є те, що у випадку, коли правова норма не відповідає принципу справедливості, держава має можливість реалізувати несправедливі правові норми, застосовуючи державний примус. У такому випадку права та свободи людини не захищаються. Часто на практиці до принципу справедливості ставляться досить формально. Суди загальної юрисдикції повинні активно реалізовувати даний принцип при здійсненні правосуддя. Так, Конституційний Суд України часто посилається у своїх рішеннях на принцип справедливості. Вимогою справедливості є однакове застосування закону до осіб, які знаходяться в однакових ситуаціях і диференційованого - до суб'єктів, які знаходяться в різних ситуаціях. Справедливістю часто спекулюють. Усі закони та судові рішення повинні бути справедливими. В іншому випадку вони не сприймаються в суспільстві, і це призводить до правового нігілізму. Принцип справедливості - це основоположний принцип для всіх галузей права. Справедливість стоїть на п’єдесталі принципів права. Тому під час вирішення конкретної проблеми юристи мають діяти справедливо, відповідно до вимог права.
\end{abstract} горія.

Ключові слова: справедливість, принципи права, суд, суддя, моральна категорія, правова кате-

\title{
Summary
}

Shelever $N . V$. Justice as a fundamental principle of law. - Article.

Justice is a fundamental principle that interests theorists and legal practitioners. A question of justice is examined by philosophers and lawyers. In his article, the author explores the place and importance of justice system principles of law. Justice is a generally rights principle of which in his the works wrote Aristotle, V. Nersesyants. The right is associated with justice. These are two categories that complement each other. The content of the rights inheres justice. The law must be fair, as it is a criterion of its legitimacy. Justice is a moral category. Morality is the source of the principle of fairness. Consider justice as a philosophical-ethical category, and as a legal category. Justice is dynamic. It contains elements of injustice, but it depends on the legal, economic, political and other relations. Often justice is compared with equality. This is stated in the universal Declaration of human rights. Justice is very important in the practice of law. The question of fair or unfair is painful for Ukrainians. An example is the market of the Ukrainian land, nationalization of PJSC CB «PrivatBank» unfair wages in Ukraine. The problem in practice is that in the case when the legal norm is incompatible with the principle of justice the state has the opportunity to realize unjust legal rules applying state coercion. In this case, the rights and freedoms of the individual are not protected. Often in practice, fairness is treated rather formally. Courts of General jurisdiction shall actively implement this principle in the administration of justice. So, the constitutional Court of Ukraine often refers in its decisions to the principle of justice. The requirement of justice is equal application of the law to persons in similar situations and differentiated to subjects who are in different situations. Justice is often being speculated. All laws and judgments must be fair. Otherwise they are not perceived in society and this leads to legal nihilism. The principle of justice is a fundamental principle for all areas of the law. Justice stands on the pedestal of law principles. Therefore, when solving concrete problems lawyers must act fairly, in accordance with the requirements of the law.

Key words: justice, principles of law, court, judge, moral category, legal category. 